Greece \& Rome, 67.2 177-202 (c) The Author(s) 2020. This is an Open Access article, distributed under the terms of the Creative Commons Attribution licence (http://creativecommons.org/ licenses/by/4.0/), which permits unrestricted re-use, distribution, and reproduction in any medium, provided the original work is properly cited.

\title{
POETRY ON THE ADVANCE: THE EMERGENCE AND FORMATION OF A POETIC CULTURE IN ROMAN BRITAIN*
}

Reflecting on the usefulness of popularity to a poet, when esteem alone is not enough to pay one's bills, Martial writes:

\author{
Non urbana mea tantum Pipleide gaudent \\ otia nec uacuis auribus ista damus, \\ sed meus in Geticis ad Martia signa pruinis \\ a rigido teritur centurione liber, \\ dicitur et nostros cantare Britannia uersus. \\ quid prodest? nescit sacculus ista meus. \\ at quam uicturas poteramus pangere chartas \\ quantaque Pieria proelia flare tuba, \\ cum pia reddiderint Augustum numina terris, \\ et Maecenatem si tibi, Roma, darent!
}

\section{5}

10

Not alone does Rome's leisure rejoice in my Pipleis, nor do I give these pieces only to empty ears. My book is thumbed by hard centurions beside Mars' standards in Getic frosts, and Britain is said to recite my verses. What's the use? My purse knows nothing of all that. Ah, but what immortal pages could I indite, what mighty battles could I blow on Pierian trumpet, if, in restoring Augustus' divinity to earth, the gods in their benevolence had given Rome a Maecenas too!

(Mart. 11.3) ${ }^{1}$

Martial implies that Nerva's restoration should have included provision of well-endowed patronage of the arts as well - funds to match Martial's popularity across the entire Roman world. ${ }^{2}$ Not commonly at the centre

* This project has received funding from the European Research Council under the European Union's Horizon 2020 research and innovation programme (grant agreement no. 832874, MAPPOLA).

1 Translation from D.R. Shackleton Bailey (ed. and trans.), Martial. Epigrams, Volume III (Cambridge, MA, 1993).

2 See e.g. L. Roman, Poetic Autonomy in Ancient Rome (Oxford, 2014), 319. On Martial and literary patronage, see especially R. R. Nauta, Poetry for Patrons. Literary Communication in the Age of Domitian (Leiden, 2002); and R. R. Nauta, 'Die mächtigen Freunde des Spötters: Martial und seine Patrone', in W. Eck and M. Heil (eds.), Senatores populi Romani. Realität und mediale Präsentation einer Führungsschicht (Stuttgart, 2005), 213-28. 
of attention, yet altogether remarkable in this epigram, is how Martial presents the dissemination and popularity of his works. Two aspects stand out. First, the circulation of his works is attributed to the Roman military (sed meus. . ad Martia signa... / a rigido teritur centurione liber, lines 3-4). Secondly, that circulation is imagined to reach the very extremes of the Roman Empire, ${ }^{3}$ from the 'Getic frosts' (line 3) to allegedly (dicitur) - Roman Britain, where Martial believed that his verses were recited (nostros cantare Britannia uersus, line 5). ${ }^{4}$

The way in which the Roman army, as a major factor contributing to relative mobility of individuals within the Roman Empire, ${ }^{5}$ may be thought of as a driver behind the diffusion and general dynamic of Roman poetry and song, has not sufficiently been explored. ${ }^{6}$ Similarly, regionalized approaches to poetry and song as a cultural practice, subject to local, ethnic, social, and cultural variation and change, have not yet been pursued in a research context in which Roman poetry has largely remained a domain of study in upper-class entertainment and intertextuality. ${ }^{7}$ Not only is the common approach at odds with a methodology that has long, and successfully, been adopted otherwise in historical and linguistic research: it also excludes the vast majority of surviving poems from the Roman world, the Carmina Latina Epigraphica, from consideration ${ }^{8}$ - a body of texts that provides us with information about a cultural practice that, subject to substantial

${ }^{3}$ See R. Evans, 'Containment and Corruption: The Discourse of the Flavian Empire', in A. Boyle and W. J. Dominic (eds.), Flavian Rome. Culture, Image, Text (Leiden, 2002), 255-76, esp. 256 with n. 8.

${ }^{4}$ B. Baldwin, 'African and British Lawyers in Juvenal', Hermes 117 (1989), 379: 'for the sake of my country's reputation for literary taste, I hope this was not true!' On the actual evidence for the awareness of Rome's literary poetry in Britain, see e.g. A. A. Barrett, 'Knowledge of the Literary Classics in Roman Britain', Britannia 9 (1978), 307-13.

${ }^{5}$ For recent discussions of mobility in the Roman Empire, see the papers collected in L. de Ligt and L. E. Tacoma (eds.), Migration and Mobility in the Early Roman Empire (Leiden and Boston, MA, 2016); and E. Lo Cascio and L. E. Tacoma (eds.), The Impact of Mobility and Migration in the Roman Empire. Proceedings of the Twelfth Workshop of the International Network Impact of Empire (Rome, Fune 17-19, 2015), Impact of Empire 22 (Leiden and Boston, MA, 2016).

${ }^{6}$ Important groundwork on this topic, not least with a view to linguistic instruction and education within the centurionate, has been carried out by J. N. Adams, 'The Poets of $\mathrm{Bu}$ Njem: Language, Culture and the Centurionate', $\mathcal{F R S} 89$ (1999), 109-34.

${ }^{7}$ For relevant methodological considerations on this subject, see now P. Kruschwitz, 'Ballistas Grabepigramm zwischen Kreativität und Tradition: Gedanken zur römischen Gedichtkultur', Gymnasium 126 (2019), 147-65, esp. 163-5.

${ }^{8}$ For a comprehensive introduction to this body of texts, see now M. G. Schmidt, 'Carmina Latina Epigraphica', in C. Bruun and J. Edmondson (eds.), The Oxford Handbook of Roman Epigraphy (Oxford, 2014), 764-82. 
regional variation, ${ }^{9}$ literary poets stylized and drove to its artistic extremes.

When Rome's establishment first began to take notice of Britain, in the context of Caesar's expeditions, there does not appear to have been much expectation of any advanced poetic culture in this area. Cicero, in a letter to Atticus written in the context of Caesar's expedition of 54 BC, expressed little hope in the existence of any musical culture in Britain that would be worth mentioning: ${ }^{10}$

etiam illud iam cognitum est, neque argenti scrupulum esse ullum in illa insula neque ullam spem praedae nisi ex mancipiis; ex quibus nullos puto te litteris aut musicis eruditos exspectare.

It is also now ascertained that there isn't a grain of silver on the island nor any prospect of booty apart from captives, and I fancy you won't expect any of them to be highly qualified in literature or music!

(Cic. Att. 4.17.7) ${ }^{11}$

Conversely, Agricola, governor of Britain after the more successful Claudian conquest of Britain almost a century after Caesar's failed campaigns, felt the need to 'upskill' the offspring of Britain's establishment in order for them to become functioning members of the Roman society: ${ }^{12}$

iam uero principum filios liberalibus artibus erudire, et ingenia Britannorum studiis Gallorum anteferre, ut qui modo linguam Romanam abnuebant, eloquentiam concupiscerent. inde etiam habitus nostri honor et frequens toga; paulatimque discessum ad delenimenta uitiorum, porticus et balinea et conuiuorum elegantiam. idque apud imperitos humanitas uocabatur, cum pars seruitutis esset.

Moreover he began to train the sons of the chieftains in a liberal education, and to give a preference to the native talents of the Briton as against the trained abilities of the Gaul.

${ }^{9}$ C. Fernández Martínez, Carmina Latina Epigraphica de la Bética Romana. Las primeras piedras de nuestra poesía (Seville, 2007) thus, entirely appropriately, speaks of this poetry as the first building blocks of 'our' (i.e., in this instance, the Bética's) poetry.

${ }^{10}$ At the same time, this provided some with an opportunity to write poetry about Caesar's campaigns: see P. Kruschwitz, 'Gallic War Songs (II): Marcus Cicero, Quintus Cicero, and Caesar's Invasion of Britain', Philologus 158 (2014), 275-305.

${ }_{11}$ Translation from D.R. Shackleton Bailey (ed. and trans.), Cicero. Letters to Atticus, 3 vols. (Cambridge, MA, 1999).

12 On the underlying idea of 'integration' see P. V. Cova, 'L'integrazione dei Britanni secondo Tacito, Agr. 21', BSL 40 (2010), 62-65; see also K. Clarke, 'An Island Nation: Re-Reading Tacitus' Agricola', FRS 91 (2001), 94-112. For a discussion of Tacitus' comments on liberty and slavery in the Agricola, see now M. Lavan, 'Slavishness in Britain and Rome in Tacitus' Agricola', CQ n.s. 61 (2011), 294-305; and A. Damtoft Poulson, 'The Language of Freedom and Slavery in Tacitus' Agricola', Mnemosyne 4th ser. 70 (2017), 834-58. 
As a result, the nation which used to reject the Latin language began to aspire to rhetoric: further, the wearing of our dress became a distinction, and the toga came into fashion, and little by little the Britons went astray into alluring vices: to the promenade, the bath, the well-appointed dinner table. The simple natives gave the name of 'culture' to this factor of their slavery.

(Tac. Agr. 21.2) ${ }^{13}$

Tacitus presents matters as though the promotion and spread of Roman-style education and culture (whatever that actually means, considering that the arrivals themselves were rather more heterogeneous than the collective noun 'the Romans' would seem to imply) simply replaced what had existed before. ${ }^{14} \mathrm{~A}$ much more plausible scenario is, of course, that elements of cultural practice and learning created a fusion that was unique and specific to Roman Britain, drawing its unique nature from already diverse local substrates ${ }^{15}$ just as much as from Roman mainstream culture and local practices, but also from individual preferences, ${ }^{16}$ reflecting the background of all those who acted on Rome's behalf, though they themselves too in their composition reflected the rich and complex ethnic and linguistic diversity of the Roman Empire. ${ }^{17}$

An interesting question to consider in this context, especially with a view to the alleged rapid development from the putative absence of a poetic culture (according to Cicero) to the arrival and circulation of literary epigram (according to Martial), not least by the hands of the Roman occupying forces, is this: how did the poetic landscape of

${ }^{13}$ Translation from M. Hutton and R. M. Ogilvie (eds. and trans.), Tacitus. Agricola. Germania. Dialogus (Cambridge, MA, 1970).

${ }^{14}$ Aspects of rhetorical and legal training in Roman Britain are touched upon in Baldwin (n. 4).

${ }^{15}$ See D. J. Mattingly, 'Urbanism, Epigraphy and Identity in the Towns of Britain under Roman Rule', in H. M. Schellenberg, V.-E. Hirschmann, and A. Krieckhaus (eds.), Roman Miscellany. Essays in Honour of Anthony R. Birley on His Seventieth Birthday (Gdansk, 2008), 53-71.

${ }^{16}$ This aspect was raised in a slightly different context by C. Johns, 'Art, Romanisation, and Competence', in S. A. Scott and J. Webster (eds.), Roman Imperialism and Provincial Art (Cambridge, 2003), 9-23.

${ }^{17}$ For the archaeological record, see H. Eckardt, 'A Long Way from Home: Diaspora Communities in Roman Britain', in H. Eckardt (ed.), Roman Diasporas. Archaeological Approaches to Mobility and Diversity in the Roman Empire, $\mathcal{F R L}$ suppl. 78 (Portsmouth, RI, 2010), 99-130. See also e.g. S. James, "Romanization" and the peoples of Britain', in S. Keay and N. Terrenato (eds.), Italy and the West. Comparative Issues in Romanization (Oxford, 2001), 187-209; and I. Haynes, Blood of the Provinces. The Roman Auxilia and the Making of Provincial Society from Augustus to the Severans (Oxford, 2013), 301-36 (especially with a view to linguistic aspects, orally and in writing). For earlier work on the 'Romanization' and 'acculturation' of Britain see, e.g. M. Millett, The Romanization of Britain (Cambridge, 1990); and M. Millett, 'The Romanization of Britain: Changing Perspectives', Kodai 13-14 (2003-4), 169-72. 
Roman Britain take shape? What were its characteristics, and what were its specifics? Where did poetry play its role, and to what ends was it used? 18

Next to nothing appears to be known, and presumably can be known, about song as a cultural practice of the Britons prior to the Roman conquest, ${ }^{19}$ not least because there was no widespread use of writing systems among the local tribes. ${ }^{20}$ In that regard, it is also next to impossible to capture the specifics of the transformative impact that the arrival of the Roman forces and the Roman establishment in Britain had on local practices. Based on the census, and elucidation, of the Latin verse inscriptions from Roman Britain, however, ${ }^{21}$ as well as mindful of the ultimately random nature of the material that has come to light so far, it is possible to gain a rather better understanding of the poetic landscape that formed in Britain from the mid-first century AD onwards. ${ }^{22}$ The following review will take stock of the evidence with a view to both chronological and geographical contexts, in order to understand the ways in which poetic practices began to establish themselves across the island. ${ }^{23}$

18 This research extends a number of considerations first developed in P. Kruschwitz, 'Rocky Starts: The Arrival of Roman Poetry in Britain', Omnibus 76 (2018), 17-19. Foundations to this research were laid by P. Cugusi, 'Carmi epigrafici della Britannia', RAL 9 (2006), 199-232, esp. 226-31 (an updated version of which was subsequently published as P. Cugusi, 'Carmi latini epigrafici della Britannia (CLEBrit' ${ }^{2}$ ', Epigraphica 76 [2014], 355-407, esp. 391-7): while Cugusi covered aspects of chronology and geographical spread, he did not consider in greater detail matters of social, ethnic, and historical patterns that emerge from the overall spread of texts across time and space.

${ }^{19}$ But see e.g. S. Piggott, 'The Carnyx in Early Iron Age Britain', Antf 39 (1959), 19-32.

${ }^{20}$ Further on this, see e.g. J. H. C. Williams, 'Coin Inscriptions and the Origins of Writing in Pre-Roman Britain', British Numismatic fournal 71 (2001), 1-17. More broadly on the arrival of Latin in Britain, see J. N. Adams, The Regional Diversification of Latin, 200 B.C.-A.D. 600 (Cambridge, 2007), 577-9.

21 This is based on my edition in P. Kruschwitz, Undying Voices. The Poetry of Roman Britain, 2015, <https://thepetrifiedmuse.blog/undying-voices/>, accessed 21 May 2020, with the addition of P. Kruschwitz, "I shall touch it with care and respect': À Propos an Hitherto Neglected Senarius from Roman Britain (EE VII 928 = RIB 659)', ZPE 204 (2017), 24-6.

${ }^{22}$ Important editorial and in-depth philological work on the verse inscriptions of Roman Britain has been published in Cugusi 2006 (n. 18) (and the subsequent update in Cugusi 2014 [n. 18]); V Asciutti, 'Poetic Britannia: A Census of Latin Verse Inscriptions', unpublished PhD thesis, King's College London (2010); and M. Schumacher, 'Die Carmina Latina Epigraphica des römischen Britannien', PhD thesis, Freie Universität Berlin (2012), <https://refubium.fu-berlin.de/handle/fub188/13698>, accessed 21 May 2020.

${ }^{23}$ The question as to which literary texts would appear to have informed the writers, while an interesting one, will be excluded from the discussion here, as there is no evidence either way that would prove (or disprove) the actual existence of editions in Roman Britain (however likely this scenario may have been): bearing in mind the relatively high level of mobility of new arrivals to Britain, it is not at all clear whether they resorted to local resources or relied on previously acquired knowledge. 
Arguably the oldest surviving monumental verse inscription from Roman Britain comes from Wroxeter (Shropshire). The text, inscribed on a sandstone monument dated to the first century AD, commemorates the life of an eagle-bearer of the fourteenth legion. It reads as follows:

\author{
[T(itus) Fl]aminius T(iti filius) Pol(lia tribu) Fa[u(entia)] \\ [an]norum XXXXV stip(endiorum) XXII mil(es) leg(ionis) \\ [XII]II Gem(inae) militaui aq(uilifer), nunc hic s[u]m. \\ [Haec?] legite et felices uita plus min[us] e[ste]: \\ [d]i uua(m) uini et aqua(m) prohibent, ubi \\ Tartar(a) aditis; uiuite, dum si[dus] \\ uitae dat tempus, honeste.
}

Titus Flaminius, son of Titus, of the tribus Pollia, from Faventia, aged 45: with 22 years of service as soldier of the 14th legion 'Gemina' I was bearer of the eagle: now I am here.

Read these words, and be happy in your life, more or less: as you approach the underworld, the gods deny you the wine's grape and water.

Live life honestly, while the star of life permits. ${ }^{24}$

Titus Flaminius, originally also represented in a sculpture above the inscribed text, is introduced with his full credentials as a Roman citizen in his nomenclature, as well as described as a long-serving, ranking military man in a distinguished position. Hailing from Faventia in Cisalpine Gaul, he is introduced in the first person and states his fate: nunc hic sum, 'now I am here' - far away from Faventia, in Britain, and no longer among the living. His final thoughts, as suggested by the poetic part of this inscription, a poem in three hexameters (lines 4-7) addressing a general audience, concern the pleasures of a life far away from the place of his eternal rest - the grapes that make the wine, and water. The advice he gives is simple: live life with decency while you can.

The military unit mentioned in this inscription, the Legio XIV Gemina, was involved in the Claudian invasion of Britain, as well as in the Roman response to the revolt of Boudicca, and from the legion's

${ }^{24} E E$ ix. $534=C I L$ vii. $154=C L E 806=R I B$ i. 292 (see also p. 76 ) $=$ Undying Voices 3 . All translations of inscriptions are my own. Further on this piece, see Cugusi 2006 (n. 18), 202-3, no. $1=$ Cugusi 2014 (n. 18), 357-9, no. 1; Schumacher (n. 22), 54-72, no. 2 (with photo); and R. S. O. Tomlin, Britannia Romama. Roman Inscriptions E Roman Britain (Oxford and Philadelphia, 2018), 29-30, no. 2.11. 
nomenclature in this inscription one may even reasonably deduce that Titus Flaminius had died before the Boudiccan revolt. ${ }^{25}$ While there can be no certainty at all that this is the oldest Latin poem ever written or recorded in Britain, it is certainly both an appealing and not an unreasonable thought that poetry arrived in the knapsacks of the Roman army - almost in the way in which Martial imagined. This picture does not change immediately as time progresses.

Poetry as an export is also the very idea behind what appears to be the second-oldest item of Latin verse recorded in Roman Britain thus far - a recently discovered, not yet fully documented inscription on a stylus (a writing utensil of all things!), dated to around AD 62-70, from the Bucklersbury site in the City of London. The text, engraved in four lines on the stylus, was given and translated as follows by Roger Tomlin:

\author{
Ab urbe u[e]n[i] munus tibi gratum adf(e)ro \\ aecul[eat]um ut habe[a]s memor[ia]m nostra(m) \\ rogo si fortuna dar[e]t quo possem \\ largius ut longa uia ceu sacculus est (u)acuus
}

I have come from the city. I bring you a welcome gift with a sharp point that you may remember me. I ask, if fortune allowed, that I might be able (to give) as generously as the way is long and as my purse is empty. ${ }^{26}$

Slightly later, from the turn of the first to second century AD, dates an inscription from York, in which a father - a soldier or a veteran, most likely ${ }^{27}$ - mourns the loss of his daughter at the age of thirteen:

\author{
[D(is)] M(anibus). \\ Corellia Optata an(norum) XIII. \\ Secreti Manes, qui regna \\ Acherusia Ditis incoli- \\ tis, quos parua petunt post \\ lumina uit(a)e exiguus cinis
}

${ }^{25}$ See T. Franke, 'Legio XIV Gemina', in Y. Le Bohec and C. Wolff (eds.), Les Légions de Rome sous le Haut-Empire. Actes du congrès de Lyon, 17-19 septembre 1998, 2 vols. (Paris, 2000), i.191-202, esp. 193-4.

${ }^{26} \mathrm{R}$. Tomlin in University of Oxford, Centre for the Study of Ancient Documents, Newsletter 21 (Spring 2018), 4-5, with drawings.

27 The nomenclature is inconclusive. One must note the absence of any mention of the mother. The daughter's name, Optata, might suggest a family link to North Africa, where names of this type were particularly frequent, though the onomastic clue, without any supporting evidence, is by no means compelling. 
et simulacrum, corpo $<r>$ is um-

bra: insontis gnat(a)e geni-

tor spe captus iniqua

supremum hunc nat(a)e

miserandus defleo finem.

$Q$ (uintus) Core(lius) Fortis pat(er) f(aciendum) c(urauit).

To the Spirits of the Departed.

Corellia Optata, aged 13.

Reclusive Manes, inhabiting the Acherusian realm of Hades,

whom a little pile of ashes and the spirit do seek

after but a short light of life - the body's shade:

I, the begetter of an innocent daughter,

trapped by wrongful hope, wretched,

wail this, my daughter's ultimate destiny.

Quintus Corellius Fortis, the father, had this made. ${ }^{28}$

Also from York, and unambiguously related to Rome's military establishment, another early poetic line, dating to earlier than AD 120, when the doomed Legio IX Hispana received its marching orders, is preserved on an altar dedicated to Silvanus by the secretary to the legionary legate:

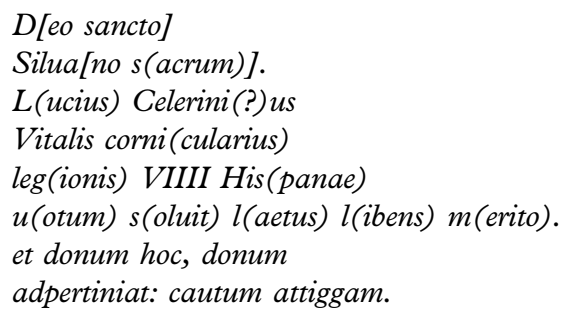

Sacred to the saint god Silvanus.

Lucius Celerin(i?)us Vitalis, cornicularis of the Legio IX Hispana, fulfilled his pledge happily, willingly, and deservedly.

And this gift, let the gift pertain: I shall touch it with care and respect. ${ }^{29}$

With two funerary and one votive inscription, admittedly a small sample size, the earliest evidence for this emerging cultural practice in

${ }^{28}$ CIL vii. $250=$ CLE $395=$ RIB i.684 = Undying Voices 1 . Further on this piece, see Cugusi 2006 (n. 18), 203-4, no. $2=$ Cugusi 2014 (n. 18), 359-61, no. 2; Schumacher (n. 22), 32-53, no. 1 (with photo); and Tomlin (n. 24), 362, no. 12.72.

${ }^{29} E E$ vii. $928=R I B$ i.659. Further on this piece see now Kruschwitz 2017 (n. 21). 
Roman Britain first appears in the exact contexts in which it also dominated outside Britain. ${ }^{30}$

\title{
III
}

\begin{abstract}
As Roman military units advanced further to the north, poetry followed, albeit - at least initially - not in its monumental form and shape. Poetry evocative of, but not directly based on, Virgil reached Hadrian's Wall at Lodge Crag by Low Row (Cumbria), where individuals, presumably while quarrying stones for the fortification efforts related to Rome's frontier and its associated structures, inscribed the following graffito:
\end{abstract}

Aurea per caelum uolitat Victoria pennis

Golden Victory flutters through the sky with her wings. ${ }^{31}$

${ }^{30}$ A number of texts that were discussed as carmina epigraphica from Roman Britain by others will be omitted from the present considerations. These include the following:

- Certainly, or almost certainly, not metrical:

${ }^{\circ} E E$ vii.1141; RIB ii.2491.147 = Undying Voices 12 (P. Kruschwitz, 'Going Out On the Tiles: RIB 2491.147', ZPE 196 [2015], 307-12);

- RIB ii.2503.102 (Schumacher [n. 22], 171-5, no. 15 [with photos], but cf. Cugusi 2006 [n. 18], 214-15, no. $13=$ Cugusi 2014 [n. 18], 374-5, no. 13, in favour of a metrical nature, but reliant on the assumption of false quantities);

${ }^{\circ} C I L$ vii.229 = RIB i.594 (Schumacher [n. 22], 157-62, no. 12, but cf. Cugusi 2006 [n. 18], 224, no. $25=$ Cugusi 2014 [n. 18], 388, no. 25);

${ }^{\circ}$ RIB ii.2503.104 (Schumacher [n. 22], 169-70, no. 14, but cf. Cugusi 2006 [n. 18], 2245, no. $26=$ Cugusi 2014 [n. 18], 389, no. 26);

${ }^{\circ}$ RIB ii.2503.381 (Schumacher [n. 22], 205-7, no. 21, but cf. Cugusi 2006 [n. 18], 2256 , no. $28=$ Cugusi 2014 [n. 18], 390-1, no. 28).

- Not datable to the period of Roman occupation of Britain:

${ }^{\circ} C L E 346=R I B$ ii.22415.72-3 (medieval: see Schumacher [n. 22], 26-8, but cf. Cugusi 2006 [n. 18] 214-15, no. $19=$ Cugusi 2014 [n. 18], 381-3, no. 19);

${ }^{\circ}$ RIB ii.2414.2a (late fifth or early sixth century: see Schumacher [n. 22], 28-9, but cf. Cugusi 2006 [n. 18], 221-2, nos. 21-2 = Cugusi 2014 [n. 18], 385-6, nos. 21-2);

${ }^{\circ} C L E 714=I L C V 1114$ (mid-sixth century AD: see Cugusi 2006 [n. 18], 223-4, no. $24=$ Cugusi 2014 [n. 18], 387-8, no. 24).

- Not from Roman Britain and not datable to the period of Roman occupation:

${ }^{\circ}$ CLE 2080 (but see Cugusi 2014 [n. 18], 398-9).

Inclusion of the texts listed in the first category, in the event of disagreement with the decisions taken here, would not alter the qualitative picture that emerges from the texts utilized for the present study in terms of chronology, spread, and sociology.

${ }^{31}$ CIL vii.844a - RIB i.1954= Undying Voices 6c. Further on this piece, see Cugusi 2006 (n. 18), 211, no. $11=$ Cugusi 2014 (n. 18), 369-70, no. 11; Schumacher (n. 22), 93-7, no. 5 . 
Possibly alluding to the honorific title of the Legio VI Victrix Pia Fidelis, and thought to have been inscribed in conjunction with the drawing of an altar and an express mention of the said sixth legion, ${ }^{32}$ Latin verse thus emerged barely a mile away from what was then the north-westernmost frontier of the Roman Empire. ${ }^{33}$ Somewhat further to the east, at Vindolanda (near Hexham, Northumberland), and presumably from a date slightly later in the second century AD as well, at least a couple of writers appear to quote Virgil more directly still - possibly in the context of writing exercises (though one cannot be certain about that). ${ }^{34}$

By the late second and early third century AD, verse at Rome's northwesternmost frontier had begun to manifest itself in more monumental forms. Two pieces discovered in the area of Habitancum (Risingham, Northumberland) would appear to convey an idea of the lives and hardship endured by members of Rome's military in hostile climes. The first one of these, from Habitancum itself, is an altar dedicated to the Nymphs in response to a premonition that one Fabius, a soldier, had in his dream:

Somnio prae-
monitus
miles hanc
ponere ius-
sit
aram quae
Fabio nup-
ta est Nym-
phis uene-
randis.

Forewarned

in a dream

32 RIB i.1953.

${ }^{33}$ The Legio VI Victrix appears to have arrived from Germany in AD 122: see L. Keppie, 'Legiones II Augusta, VI Victrix, IX Hispana, XX Valeria Victrix', in Le Bohec and Wolff (n. 26), i.25-37, esp. 30 (with nn. 67-9). On the legion more generally, see e.g. A. R. Birley, 'VI Victrix in Britain', in R. M. Butler (ed.), Soldier and Civilian in Roman Yorkshire (Leicester, 1971), 82-96.

34 This explanation has commonly been adopted for the dialogical text of $T$. Vindol. II $118=$ Undying Voices 11, on which see now P. Kruschwitz, 'T.Vindol. II 118: An Obscene Joke from Vindolanda?', Tyche 29 (2014), 271-2. A second potential reference to Virgil, though rather more problematic than the previous case, was noted for T. Vindol. II 121. (A problem not commonly addressed in the context of alleged writing exercises is the question as to why, in virtually all cases, any given text only ever appears once: is repetitio est mater studiorum ['repetition is the mother of learning'] not a key principle for any writing exercise?) 


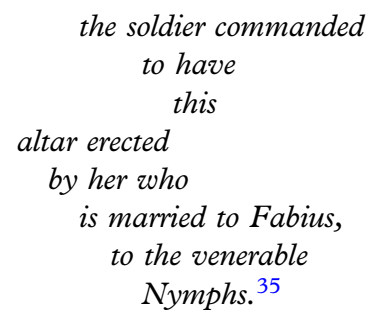

While the nature of the premonition as such remains unclear, it is remarkable, and presumably meaningful, how specific the response is: not just an altar erected by Fabius, but, in fact, by his wife (whose name remains unknown). ${ }^{36}$ It may not be altogether absurd to infer that the dream involved some type of ill omen with an impact on the soldier's wife and, considering the recipients of this altar, involving, or affecting, an aspect of nature, such as the life-giving powers of a local spring.

Life in a challenging environment has also been the theme in a second poetic piece, a heavily damaged funerary monument that was discovered near Habitancum, but north of Hadrian's Wall (though it may have been moved to its eventual findspot for its secondary use):

$$
\begin{aligned}
& \text { [- - - Flam]inii ++nsae } \\
& \text { [- - -]ae dominar- } \\
& \text { [- - se]mper geli- } \\
& \text { [dis - - -]te pruinis } \\
& \text { [- - -]++ qui sib[i] } \\
& \text { [- - -]++++AS } \\
& \text { [- - ]+FICTNI } \\
& \text { [- - - ]+ue frag- } \\
& \text { [- - }]+E \text { tibi pro } \\
& \text { [- - ]rce pro } \\
& \text { [- - ] Flaminius o- } \\
& \text { [- - ]e profund- } \\
& \text { [- - l]ucem uolu- } \\
& \text { [it - - -]dere uitae. }
\end{aligned}
$$

${ }^{35}$ CIL vii. $998=C L E 263=$ RIB i. $1228=$ Undying Voices 17 . Further on this piece, see Cugusi 2006 (n. 18) 210-211 n. 10 = Cugusi 2014 (n. 18) 368-369 n. 10, Schumacher (n. 22) 8792 n. 4, and Tomlin (n. 24) 208 n. 9.15 (with photo).

${ }^{36}$ Tomlin (n. 24) 208 speculates that Fabius, possibly of Northern African extraction and in command of a military unit, is identical with one Fabius Honoratus mentioned in $R I B$ 1482 (at Chesters), where a wife, Aurelia Eglectiane, is also mentioned. This is a plausible, but by no means certain, assumption: for one thing, miles would seem something of an understatement for Fabius, if he had indeed been the commander of a unit at the time. 
...of Flaminius. . .nsa

...dominate

... always in cold

...frost

...who himself

$\ldots$

...broken

...to you for

...(spare?) for

...Flaminius...

...shed

...light...he want-

ed. . of life. ${ }^{37}$

Although the heavily damaged state of this piece does not allow for any confident conclusions, the dread of northern frost and darkness seems palpable from the few words that do survive in the text.

The sky is also the theme in the final piece to be considered here, a dedication erected by one Marcus Caecilius Donatianus, a military tribune, dated to the second or third century $\mathrm{AD}$ and discovered at Carvoran (Northumberland):

\author{
Imminet Leoni Virgo caelesti \\ situ spicifera iusti inuentrix \\ urbium conditrix: \\ ex quis muneribus nosse contigit \\ deos. ergo eadem Mater diuum, \\ Pax, Virtus, Ceres, dea Syria \\ lance uitam et iura pensitans. \\ in caelo uisum Syria sidus edidit \\ Libyae colendum; inde \\ cuncti didicimus. \\ Ita intellexit numine inductus \\ tuo. Marcus Caecilius Donatianus \\ militans tribunus \\ in praefecto dono principis. \\ Virgo, in her heavenly realm, is close to Leo: \\ holding ears of grain, the inventor of justice, \\ foundress of cities:
}

${ }^{37}$ CIL vii. 1020 (cf. 312) $=$ RIB $1253=$ Undying Voices 20. Further on this piece, see Corpus Signorum Imperii Romani, Great Britain 1.8. Roman Sculpture from England (Oxford, 1994), 98 (with photo, pl. 72, no. 265); Cugusi 2006 (n. 18), 209-10, no. $9=$ Cugusi 2014 (n. 18), 367-8, no. 9; and Schumacher (n. 22), 98-107, no. 6 (with photos). 
gifts that allowed us to recognize the gods.

Thus she is also the Mother of the Gods,

Peace, Virtue, Ceres, the Syrian Goddess,

administering shares of life and justice with her scales.

Syria gave rise to this constellation, to be seen in the sky,

to be worshipped in Libya;

that is how we all have acquired our knowledge.

Thus came to understanding, persuaded by your divine will,

Marcus Caecilius Donatianus,

who serves the army as a tribune

in the post of prefect, granted by the Emperor. ${ }^{38}$

Caecilius Donatianus, a ranking officer, appears to have composed this text as a reminder that, even in a hostile setting in which one may only hope for future prosperity, in a setting in which ethnicities from across the empire - from Syria to Libya - were united not only under Roman command, but also under the same sky, everyone still had something in common: the same desires, the same hopes, and the same religious beliefs (even if expressed in different terms). ${ }^{39}$ Into this mix of unifying factors, one may well add the use of inscribed verse - mostly alien still to the stretches from which this piece hails, but common practice in Roman North Africa and the Near East.

\section{IV}

Monumental poetry in the immediate vicinity of Hadrian's Wall not only remains closely associated with Rome's military presence, but also profoundly reflects the specifics of this challenging environment and the hopes, fears, and desires of those who served the Roman Empire. Poetry behind the front lines, in turn, increasingly begins to reflect the emerging and evolving civic life of the province.

Interestingly enough, funerary commemoration in verse is not as prominently attested in Roman Britain as it is elsewhere in the

${ }^{38}$ CIL vii.759= CLE $24=$ RIB i.1791=Undying Voices 4. Further on this piece, see E. Courtney, Musa lapidaria. A Selection of Latin Verse Inscriptions (Atlanta, GA, 1995), 156-7, 364-6, no. 164; Cugusi 2006 (n. 18), 211-14, no. $12=$ Cugusi 2014 (n. 18), 3704, no. 12, J. Velaza, 'Interpretatio y sincretismo religioso en los CLE: algunos casos singulares', in X. Gómez Font, C. Fernández Martínez, and J. Gómez Pallarès (eds.), Literatura epigráfica. Estudios dedicados a Gabriel Sanders (Zaragoza, 2009), 331-51; Schumacher (n. 22), 115-34, no. 8 (with photo); and Tomlin (n. 24), 373-4, no. 12.86 (with photo).

${ }^{39}$ It is altogether unnecessary to suggest a visit of Julia Domna as the occasion that sparked the erection of this monument, as some have suggested (see e.g. Tomlin [n. 24], 373). 
Roman Empire. It is by no means altogether absent, however, as shown not only by some of the aforementioned pieces, but also, for example, by the following heavily fragmentary item from third- or fourth-century AD Lindum/Lincoln (Lincolnshire):

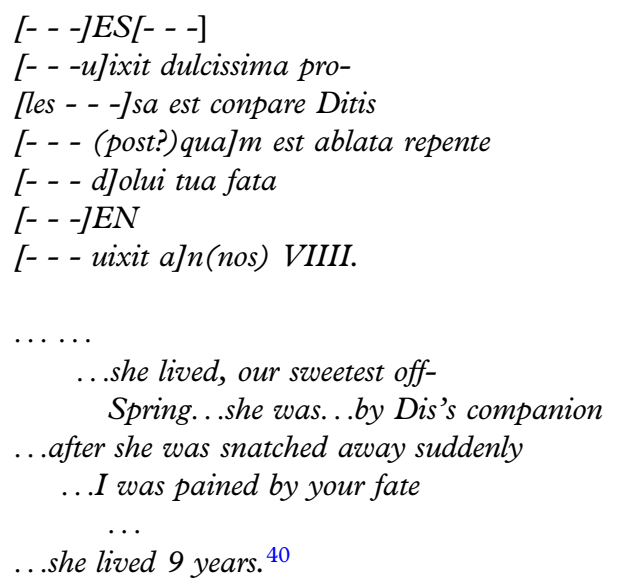

Owing to the fragmentary nature of this piece, not much can be said about the deceased and her family background.

An important peculiarity of the civic life that began to form in the province of Britannia, and that persisted throughout its existence, is its peculiar ethnic composition - a composition in which arrivals from across the Roman Empire, whether in the context of Rome's military and administrative structure or otherwise, not infrequently maintained, and wished to assert, their links to their respective ethnic and geographic origins. This desire was already tangible in the inscription of Caecilius Donatianus, and is evident in an inscription on a sarcophagus from York, tentatively dated to the second century AD:

Iul(iae) Fortunat(a)e, domo

Sardinia. Verec(undio) Diogeni

fida coniuncta

marito.

${ }^{40} E E$ ix. $1113=C L E 2267=R I B$ i. $265=$ Undying Voices 18 . Further on this piece, see Cugusi 2006 (n. 18), 216-17, no. 15 = Cugusi 2014 (n. 18), 376-7, no. 15; and Schumacher (n. 22), 108-14, no. 7 (with photo). 
For Fulia Fortunata, whose homeland was

Sardinia. To Verecundius Diogenes ${ }^{41}$

devotedly coupled,

who was her husband. ${ }^{42}$

The wish to celebrate one's non-local origins in verse remains visible, however, even in a poem dated to a time period as late as the fourth or fifth century $\mathrm{AD}$, inscribed on a tombstone discovered at Carlisle (Cumbria):

$D$ (is) $M$ (anibus).

Fla(uiu)s Antigonus Papias

ciuis $\mathrm{Gr}($ a)ecus uixit annos

plus minus LX. quem ad

modum accom(m)odatam

fatis animam reuocauit.

Septimia domina [- - -]

- . - . -

To the Spirits of the Departed.

Flavius Antigonus Papias,

Greek citizen, lived

60 years, give or take a few:

he made his soul return to the Fates,

having harboured it thus far.

Septimia...mistress...

...... ${ }^{43}$

While it remains unclear what brought Antigonus Papias to Britain, it is obvious that, though mentioned with his Roman tria nomina, it appears to have been of importance to his honourands that he was, in fact, of Greek descent and thus died away from home. ${ }^{44}$

${ }^{41}$ The same man is attested in an inscription of another sarcophagus from York, now lost, that identifies him as a sevir (a member of a board of six men, appointed to certain administrative duties) of York and the Morini, as well as a citizen of the Bituriges, a tribe from central Gaul: RIB 678.

${ }^{42} E E$ iii.183, pp. $313-14=R I B$ i.687 $=$ Undying Voices 14 . Further on this piece, see Cugusi 2006 (n. 18), 204-5, no. 3 = Cugusi 2014 (n. 18), 361-2, no. 3; Schumacher (n. 22), 151-6, no. 11 (with photo); and Tomlin (n. 24), 237, no. 9.51.

${ }^{43} E E$ ix.1222 = CLE $1597=$ RIB i.955 = Undying Voices 22. Further on this piece, see Cugusi 2006 (n. 18), 223, no. 23 = Cugusi 2014 (n. 18), 386-7, no. 23; Schumacher (n. 22), 163-8, no. 13 (with photo); and Tomlin (n. 24), 377, no. 12.91 (with photo). See also P. Kruschwitz, 'Three Short Notes on RIB 955=CLE 1597', ZPE 195 (2015), 295-6 (with photo).

${ }^{44}$ On this motif in more general terms, see e.g. M. Arena and I. Bitto, 'Il motivo della morte in terra straniera nei CLE bücheleriani', in A. Akerraz, P. Ruggeri, A. Siraj, and C. Vismara 
A third text that must be mentioned in this context comes from Brough-under-Stainmore (Cumbria) and has been dated to the third century AD. This inscription commemorates a young man called Hermes. Remarkably, this piece not only alludes to the foreign origin of Hermes, from Commagene in the very east of the Roman Empire, but also celebrates him in Greek verse:

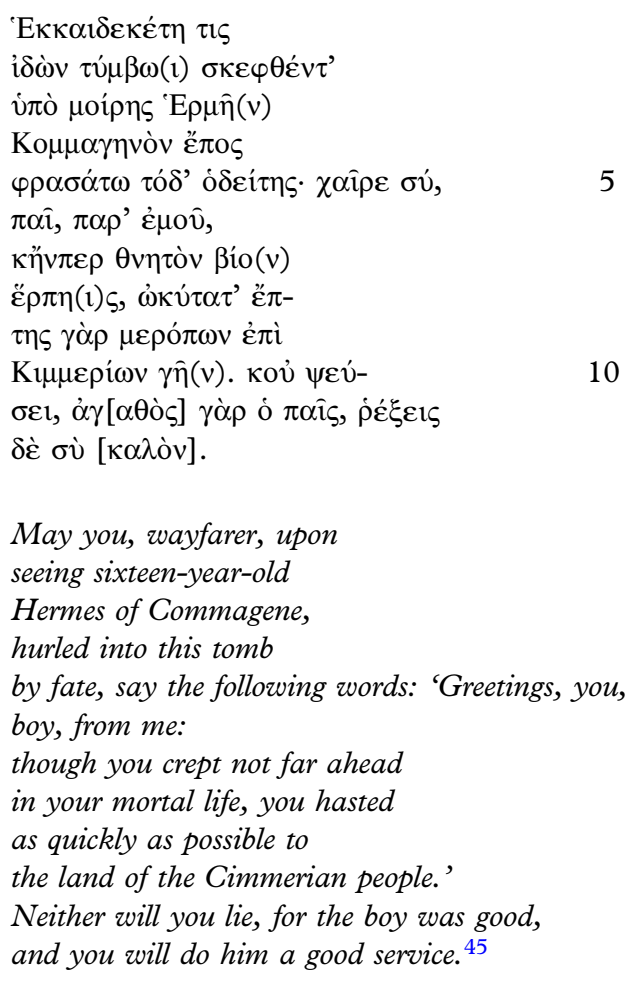

Reference to Hermes as $\pi \alpha \hat{i} \zeta$ ('boy', lines 6 and 11) of 'good' quality (line 11) may suggest that he had been a slave. Furthermore, the elaborate nature of the poem with its Homeric allusions may be taken as an indication that Hermes served someone of elevated social status - perhaps a military commander or ranking administrator.

(eds.), L'Africa romana. Mobilità delle persone e dei popoli, dinamiche migratorie, emigrazioni ed immigrazioni nelle province occidentali dell'Impero romano. Atti del XVI convegno di studio Rabat, 15-19 dicembre 2004, 4 vols. (Rome, 2006), ii.1021-42.

${ }^{45} E E$ vii. $952=I G$ xiv. $2550=R I B$ i. $758=$ Undying Voices 9. Further on this piece, see Schumacher (n. 22), 16-17, no. 2gr; and Tomlin (n. 24), 236, no. 9.50. 
Hermes' funerary poem is by no means the only Greek verse inscription that has emerged from Roman Britain, and almost all instances ${ }^{46}$ can be seen in the context of both the ethnic diversity through the influx of arrivals from the eastern half of the Roman Empire and the crosscultural fertilization that such arrivals brought about through the import of their poetic cultural practices. In two cases, this is linked to oriental cults at Corbridge (Northumberland). ${ }^{47}$ A dactylic hexameter in a third-century inscription refers to the worship of the Syrian deity of Melqart:

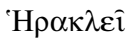 \\ Tupí( (l)

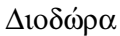

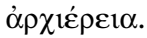 \\ For Hercules \\ of Tyre: \\ Diodora, \\ archpriestess. ${ }^{48}$
}

A second item, undated, mentions Astarte:

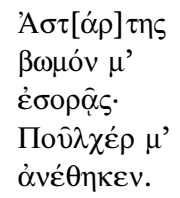

You behold me -

Astarte's

altar:

Pulcher

consecrated me. ${ }^{49}$

$(C I L$ VII p. $97=I G$ XIV 2553= RIB I 1124=Undying Voices 7$)$

${ }^{46}$ An exception is RIB i.241 (see section V, below).

${ }^{47}$ Further on Oriental cults in Roman Britain, see now E. Harris and J. R. Harris, Oriental Cults in Roman Britain (Leiden, 2015), esp. $96 \mathrm{ff}$. on the cults of Asia Minor and Syria.

${ }^{48} C I L$ vii, p. $197=I G$ xiv. $2554=$ RIB i. $1129=$ Undying Voices 13 . Further on this piece, see Schumacher (n. 22), 17-18, no. 4gr.

${ }^{49} C I L$ vii, p. $197=I G$ xiv. $2553=R I B$ i. $1124=$ Undying Voices 7 . Further on this piece, see Schumacher (n. 22), 17, no. 3gr. 
Further away from the frontier, at Chester, a member of the medical profession, presumably related to the legionary fortress and settlement of the late second century $\mathrm{AD}$, also expressed himself in Greek:

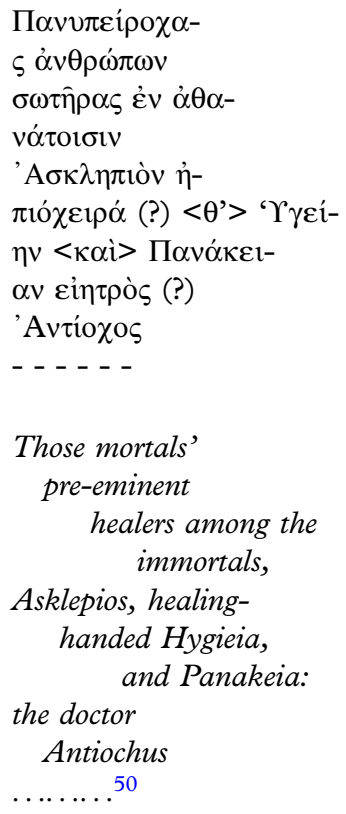

In all three instances it may have been the Greek and/or Oriental nature of the cults in question that resulted in the specific choice of language. At the same time, both the linguistic choice and the presence of the relevant cults (and the professions mentioned), not unrelated to the composition and needs of the Roman army across Britain, are testament to the actual diversity of the individuals who made up the changing population of Roman Britain.

Further poetic evidence for professions related to the presence of the Roman army and the emergence of local infrastructure, as well as the use of inscribed verse in religious contexts comes from Bownesson-Solway (Cumbria), where an inscription, tentatively dated to the third century $\mathrm{AD}$, conveys the hopes of a merchant for improvement of his financial situation:

${ }^{50}$ SEG xxxvii (1987), 260, no. $840=$ Undying Voices 21. Further on this piece, see D. R. Wilson and R. P. Wright, 'Roman Britain in 1968', $7 R S 59$ (1969), 198-246, esp. 235, no. 3 (with photo on plate XVIII, no. 2); and, more recently, J. Clackson and T. Meissner, 'The Poet of Chester', Cambridge Classical fournal 46 (2001), 1-6. 
- - - _ - 51

[Ant:] ]onianus dedico.

[s]ed date, ut fetura quaestus

suppleat uotis fidem:

aureis sacrabo Carmen

mox uiritim litteris.

I, Antonianus, dedicate this.

But grant my requests, so that the proceeds of my business may lend credence to my promises:

I will consecrate a poem, in due course -- --- with golden letters, every single one of them..$^{2}$

Especially remarkable for its objectification of poetry as a text that can be made more precious by means of expensive materials employed for its very lettering, this piece appears to commemorate the financial struggles of a merchant whose quaestus ('business') was in need of fetura ('proceeds') to such an extent that he asked for divine support. The nature of Antonianus' business is unknown, as is the reply to the question as to whether his prayers were answered. ${ }^{53}$

A final aspect related to the evolution of Roman infrastructure that had an impact on the local production and preservation of poetry in Britain was the maintenance of infrastructure at the hand of Roman officials. An altar from Catterick (North Yorkshire), datable to AD 191, provides one of two relevant examples:

\author{
Deo qui uias \\ et semitas commentus \\ est. Aur(elius) \\ Dasso $^{54} f$ (ecit) $u$ (otum) l(aetus) l(ibens) $m$ (erito).
}

${ }^{51}$ A first line has variously been restored as [Matribus deabus aed]em (see e.g. Tomlin [n. 24], 298). My autopsy of this monument in Carlisle's Tullie House Museum did not corroborate this.

${ }^{52} C I L$ vii. $952=C L E 229=R I B$ i. $2059=$ Undying Voices 5 . Further on this piece, see Cugusi 2006 (n. 18), 215-16, no. 14 = Cugusi 2014 (n. 18), 375-6, no. 14; Schumacher (n. 22), 135-45, no. 9 (with photo); and Tomlin (n. 24), 298, no. 11.23.

${ }^{53}$ With the promise of an additional carmen in the future, this text is a remarkable key to the frame of mind of an individual with regard to the potential reasons to engage in composing and inscribing verse: clearly a poem as a piece of art was deemed a valuable gift - valuable enough for it to be deemed sufficient incentive to the divine powers to support Antonianus' uotum in the first place, and then even more so, if presented in gold, as something that would satisfy them in exchange for economic success. In that respect, poetry as a manifestation of creative art appears to have the same value as e.g. a votive sculpture.

${ }^{54}$ A variant reading, $T$ (itus) Ir das $s$ (ingularis) c(onsularis), giving an otherwise unattested and implausible name, has been rejected, probably correctly, by N. B. Rankov, 'The beneficiarii 
$Q$ (intus) Varius Vitalis

$b$ (ene)f(iciarius) co(n)s(ularis) aram

sacram restituit

Aproniano et Bradua

co(n)s(ulibus).

To the god who conceived

roads and paths:

Aurelius

Dasso fulfilled his promise happily, gladly, deservedly.

Quintus Varius Vitalis,

adjutant of the governor has restored

this sacred altar

under the consulship of

Apronianus and Bradua. ${ }^{55}$

A more widely discussed piece, however, as well as a piece in which the formation of its poetic content is definitely deliberate rather than potentially merely accidental, is a fragmentary stone from Cirencester (Gloucestershire), most likely dating to the late third or early fourth century AD:

I(oui) $O$ (ptimo) $[M($ aximo $)]$

L(ucius) Sept[imius]

$u$ (ir) p(erfectissimus) pr(aeses) B[rit(anniae) pr(imae)]

resti[tuit]

ciuis $R[---]$. $\mid$

[si]gnum et

[e]rectam

[p]risca re-

[li]gione co-

[l]umnam \|

Septimius

renouat

primae

prouinciae

rector.

consularis in the Western Provinces of the Roman Empire', unpublished $\mathrm{PhD}$ thesis, Oxford (1986), 124.

${ }^{55}$ CIL vii. $271=C L E 25=I L S 3929=$ RIB i.725 $=$ Undying Voices 16 . Further on this piece, see Cugusi 2006 (n. 18), 209, no. 8 = Cugusi 2014 (n. 18), 366-7, no. 8; Schumacher (n. 22), 146-50, no. 10 (with photo); and Tomlin (n. 24), 268-9, no. 10.32 . 


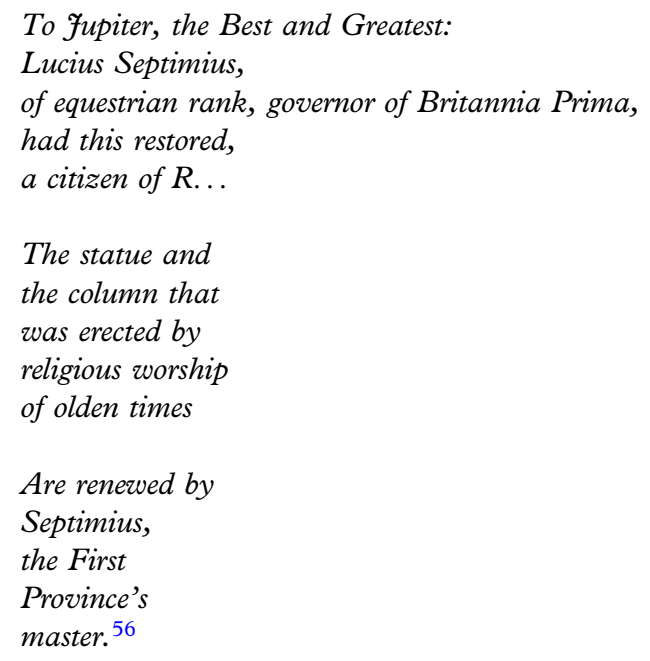

While the piece may not, as previously thought, ${ }^{57}$ belong in the context of pagan restoration under the rule of Julian the Apostate, it certainly belongs firmly in the context of celebrating infrastructural restoration in verse, adding the poem as a dignifying decorative element to an object of worship.

\section{$\mathbf{V}$}

In (reasonably) safe distance from the empire's north-westernmost frontier, centres of Roman civic life began to develop. The relative stability and prosperity of life in these areas is mirrored in the poetic record that begins to represent the stratigraphy of a Romano-British society more fully. The poetry that emerges in the south and south-east in particular, reflects, on the one hand, the desires of a consolidated upper class to engage in lavish decorative displays of status and education and, on the other hand, the ability of lower social strata to convey their humour through short compositions in the form of graffiti.

The former of these two aspects can be seen in examples of verse employed for decorative uses in elite villas in Kent. Fragments of wall plaster from a Roman villa at Otford, dated to the second century

${ }^{56} E E$ ix.997 = ILS $5435=C L E 277=R I B$ i. $103=$ Undying Voices 8. Further on this piece see Courtney (n. 38), 152-3, 361-2, no. 161; Cugusi 2006 (n. 18), 217-18, no. 16 = Cugusi 2014 (n. 18), 377-8, no. 16; and Schumacher (n. 22), 73-86, no. 3 (with photo).

${ }^{57}$ See RIB i, p. 758 , no. 103. 
$\mathrm{AD}$, quote Virgil's Aeneid, accompanied by a pictorial representation of a relevant scene:

Bina manu l[ato crispans hastilia ferro ?]

[Brandishing] two [spears with] b[road heads] in his hand... ${ }^{58}$

A large mosaic representing the abduction of Europa by Jupiter in disguise as a bull, discovered in the context of a lavish Roman villa at Lullingstone and datable to the first half of the fourth century AD, takes a witty, wholesomely feminist stance on Jupiter's escapade with a less than subtle allusion to the Aeolus episode in the first book of the Aeneid:

Inuida si t[a]uri uidisset Iuno natatus, iustius Aeolias isset ad usque domos.

Had jealous funo seen the bull's swimming attempts,

More rightfully still would she have approached the halls of Aeolus. ${ }^{59}$

Only slightly later in date than the Lullingstone mosaic, from the late fourth century AD, is another mosaic - a (damaged) piece that was discovered in the context of a Roman villa at Frampton (Dorset), in which mythical scenes were accompanied by ecphrastic verse:

Neptuni uertex, reg(i)men

sortiti mobile uentis, \|

$\operatorname{scul}(p) t u<r a>$ cui $c(a)$ erulea es [t]

delfinis cincta duob[us].

$[---]$

$[---] \|$

[mu]nus perficis ullum,

[i]gnare, Cupido.

${ }^{58}$ RIB ii.2447.9 = Undying Voices 6b. The quotation is from Verg. Aen. 1.313 or 12.165. Further on this piece, see Cugusi 2006 (n. 18), 219, no. $18=$ Cugusi 2014 (n. 18), 380, no. 18; R. Ling, 'Inscriptions on Romano-British Mosaics and Wall-Paintings', Britannia 38 (2007), 63-91, esp. 76-8 (with photos); V. Asciutti, 'Sophisticated Britannia: Classical Literature at Frampton', in R. Häussler, Romanisation et épigraphie. Études interdisciplinaires sur l'acculturation et l'identité dans l'Empire romain (Montagnac, 2008), 321-33; and Schumacher (n. 22), 235-9, no. 24 (with photo).

${ }^{59}$ RIB ii.2884.6 = Undying Voices 2. Further on this piece see M. Henig, 'The Secret of the Lullingstone Mosaic', Kent Archaeological Review, 139 (2000), 196-7; Cugusi 2006 (n. 18), 218, no. $17=$ Cugusi 2014 (n. 18), 378-80, no. 17; Ling (n. 58), 78-9 (with photo); Schumacher (n. 22), 208-18, no. 22 (with photo); and Tomlin (n. 24), 282, no. 11.02. 
The head of Neptune: a kingdom,

driven by the winds, he has been assigned.

His appearance is blue, surrounded by two dolphins.

you achieve any task, silly Cupid! 60

Rather less clear than the previous examples, yet possibly similar in a once decorative function, is the context of a (now lost, undated) piece from Wilcote (Oxfordshire). The fragment of a copper plate preserved just one word - yet the shape of the single word that survives suggests that it once was part of a poem in epic verse:

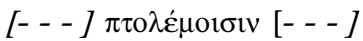

$$
\begin{aligned}
& {[---]++\mathrm{T} \Sigma(?)[---]} \\
& \text {...in battles... } \\
& 61
\end{aligned}
$$

With less focus on lavish display, but rather a desire to record one's quick wit, a small number of poetic (or, at least, poeticizing) graffiti document a consolidated poetic culture across social strata beyond the upper class. This is certainly true for an inscribed tile from Silchester (Hampshire), perhaps datable to the second century AD, in which the notorious opening of Book 2 of the Aeneid has been adopted and wittily recontextualized in what may have been a quasi-curse:

Pertacus, Perfidus,

Campester, Lucilianus,

Campanus: conticuere omnes.

Pertacus, Perfidus,

Campester, Lucilianus,

Campanus: they all fell silent. ${ }^{62}$

${ }^{60} E E$ iii, p. $311=C I L$ vii. $2=C L E 1524=R I B$ ii. $2448.8=$ Undying Voices 10 . Further on this piece, see Cugusi 2006 (n. 18), 220-1, no. $20=$ Cugusi 2014 (n. 18), 383-4, no. 20; Ling (n. 58), 79-82 (with engraving); and Schumacher (n. 22), 219-34, no. 23.

${ }^{61} E E$ ix. $1003=R I B$ i.241 = Undying Voices 19. See also Schumacher (n. 22), 16, no. 1 gr.

${ }^{62} E E$ ix. $1293=R I B$ ii.2491.148 = Undying Voices 6a. Further on this piece, see Cugusi 2006 (n. 18), 205-6, no. 4 = Cugusi 2014 (n. 18), 362-4, no. 4; and Schumacher (n. 22), 179-4, no. 17 (with photo). The same Virgilian line also appears to feature on a sherd of a bowl that was discovered at St Albans (Hertfortshire): RIB ii.2502.51 (on which see also Cugusi 2006 [n. 18], 224-5, no. 26 = Cugusi 2014 [n. 18], 389-90, no. 26); Schumacher (n. 22), 176-8, no. 
It also holds true for an actual leaden curse tablet from Kelvedon (Essex), which was read as follows and interpreted as being of iambic rhythm by Paolo Cugusi:

Quicumque res Vareni in-

uolauerit si mulrer (!) si mascel (!)

sanguno (!) suo soluat

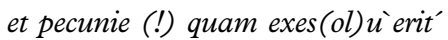

Mercurio dona(t) et Virtuti s(acra).

Whoever has stolen the property of Varenus, whether woman or man, in his own blood and from the money which he has consumed let him pay gifts to Mercury and sacred offerings to Virtue. ${ }^{63}$

( $A E$ 1959.157 = $A E 2014.781$ add., transl. R. P. Wright)

Finally, a rather puzzling matter, also almost certainly unrelated to any upper-class activity, is a recurring line that was first discovered on two tiles from Binchester (County Durham), probably dating to the third century AD. ${ }^{64}$ The shorter variant of the two reads:

Armea me docuit. ${ }^{65}$

The longer version reads:

Armea me docuit 'recte

tibi' dicere cunctis. ${ }^{66}$

which was tentatively translated as:

16, remained doubtful over the correct reading, but see now R. S. O. Tomlin, 'Roman Britain in 2014: Inscriptions', Britannia 46 (2015), 419.

${ }^{63} A E 1959.157=A E 2014.781$ add. (translation by R. P. Wright). Further on this piece, see R. P. Wright, 'Roman Britain in 1957: Inscriptions', $7 R S 48$ (1958), 150-5, esp. 150, no. 3 (with drawing); and Cugusi 2006 (n. 18), 231-2 ('Appendice') = Cugusi 2014 (n. 18), 400 ('Appendice II').

${ }^{64}$ In theory, a date in the late first century AD would also be possible. This, however, can now be ruled out with great certainty as a result of a new find (below, n. 67). - Further on both pieces see Cugusi 2006 (n. 18) 207-208 n. 5-6 = Cugusi 2014 (n. 18) 364-365 n. 5-6, Schumacher (n. 22) 185-191 n. 18 (with photo of RIB II 2491.146 (i) = Undying Voices 15 b), and Tomlin (n. 24) 289 n. 11.11.

${ }^{65} E E$ vii. $1146=E E$ ix. $1290=C L E 1939=R I B$ ii.2491.146(ii) $=$ Undying Voices 15a .

${ }^{66}$ RIB ii.2491.146(i) $=$ Undying Voices $15 \mathrm{~b}$. 
Armea (?) taught me to say

'you're right' to everyone (or: everything).

This set has very recently been supplemented by a third find, in the shape of a graffito on a pot base from East Farleigh (Kent), published by Alex Mullen and Roger Tomlin, suggesting that the text itself was a more widespread little composition, even if the overall interpretation, and especially the meaning of Armea, remain unclear. ${ }^{67}$

\section{VI}

As far as recorded poetry is concerned, Britain was a blank canvas prior to the arrival of Rome's legions: a geographical space for which it is possible to witness the emergence and formation of a cultural practice, well-established in other parts of the Roman Empire, over a discrete period of time and dependent on social, cultural, ethnic, linguistic, and economic factors that underpinned provincial life in Britain in more general terms. While there is no reason at all to suggest that poetry and song were altogether absent from Britain's pre-Roman cultures, it is clear that new arrivals imported cultural practices with which they were familiar and which held meaning to them. Down to its very end, by the time that Roman rule was lifted, poetic composition in Britain remained the domain of foreigners most of all, joined eventually by a locally formed elite.

Beginning with funerary commemoration in verse in central Britain, at least in one instance unambiguously linked to an arrival from mainland Italy, a light-heartedly inscribed writing utensil, and a religious dedication, the production of verse at first followed Rome's fighting forces to the north - very much following the logic of Martial's epigram that emphasizes a link between the spread of Roman poetry and the mobility of Rome's army. At Hadrian's Wall, after a phase of informal writing, monumentally inscribed verse began to surface, and it is from there that the empty spaces in the hinterland, all the way to the south and south-east of England, started to see an increasing engagement with poetic compositions. Eventually, as a new-style elite began to

${ }^{67}$ A. Mullen and R. S. O. Tomlin, 'More from the Romano-British Poets? A Possible Metrical Inscription from East Farleigh, Kent', Britannia 50 (2019), 47-54, who, based on a reading of as (?) mea in the newest addition to the corpus, have suggested that the especially bizarre formation Armea may, in fact, be an incorrect rendering of ars mea. 
form, even lavish decorative uses of poetry - in the shape of musive and painted texts - appeared.

When compared to other provinces, Britain developed an almost unique poetic identity in its surviving verse inscription. While funerary carmina exist, they do not, unlike in other places, dominate the material. Instead, there is an especially high number of religious texts among Britain's inscribed poems - from religious cults that are sustained and supported by state officials, to expressions of individual and personal belief, to mythical allusions. Not only in these texts, but more generally, a distinct sense of fragility, a life that is constantly under threat and in danger, prevails - a sensation that other provinces, even under similar conditions, do not appear to display to a similar extent in their verse inscriptions.

There is no teleology, inherent or otherwise, no plot in the attestation and spread of verse inscriptions anywhere in the Roman Empire - and the picture that begins to form through their study, in any given context, may be very incomplete and non-representative. Considering the small sample size of relevant texts from Roman Britain, even a very small number of additions to the corpus may have fundamentally transformative potential to analyses and interpretations. Yet the picture that seems to form through the combination of chronological and geographical information about the surviving texts on the one hand, and factors related to social, ethnic, and historical context and circumstance on the other, is a compelling one - designed to provide an in-depth understanding of verse as a cultural practice that manifests, and transforms, itself continually in the multiethnic and multilingual realities of the Roman Empire, driven by substantial levels of individual and group mobility, as well as contact and exchange of an ever-changing mixture of cultures, religions, and languages.

PETER KRUSCHWITZ 